\section{Magdalena Jóźwiak}

Papieski Wydział Teologiczny we Wrocławiu

e-mail: mjozwiak.uni.wr@gmail.com

DOI: http://dx.doi.org/10.12775/BPTh.2015.021

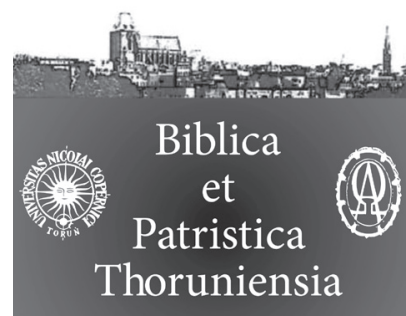

8 (2015) 3

ISSN (print) 1689-5150

ISSN (online) 2450-7059

\title{
Laudacja Czuwań w De vigiliis servorum Dei św. Nicetasa z Remezjany
}

\section{Laudation vigils in De vigiliis servorum Dei St. Nicetas of Remesiana}

\begin{abstract}
Streszczenie. De vigiliis servorum Dei, autorstwa św. Nicetasa z Remezjany jest laudacją na cześć czuwań nocnych, które powinny stać się udziałem każdego mnicha. W opinii biskupa Remezjany praktykowanie czuwań nocnych jest jedną z metod na osiągnięcie doskonałości zakonnej. Nicetas zachęcając mnichów do podjęcia czuwań, opiera swoje refleksje na autorytecie Pisma Świętego, kładąc duży nacisk na przykład i słowa o czuwaniu samego Jezusa. W swoim kazaniu poucza mnichów o starodawności i autorytecie czuwań nocnych, a co ważniejsze wylicza konkretne korzyści, jakie stają się udziałem czuwającego oraz udziela czuwającym mnichom praktycznych rad. Ten aspekt sprawia, że wskazówki kierowane do mnichów nie są zbiorem suchych zaleceń, lecz wskazują na prawdziwą troskę duszpasterską biskupa o lud mu powierzony.
\end{abstract}

\begin{abstract}
De vigiliis servorum Dei by St. Nicetas of Remesiana a laudation in honor of the night vigils, that should be experienced by every monk. In the opinion of Bishop Remesiana night vigils practice it is one of the methods to achieve religious perfection. Nicetas encouraging monks to take vigils, based his reflections on the authority of Scripture, putting much emphasis on the example and words of Jesus himself vigil. In his sermon teaches monks antiquity and authority nocturnal vigils and more importantly lists the specific benefits that are shared by watchful monks and gives practical advice. This aspect makes the guidance addressed to the monks, there are a set of recommendations dry, but show a genuine concern for the pastoral bishop of the people entrusted to him.
\end{abstract}

Słowa kluczowe: św. Nicetas z Remezjany; De vigiliis servorum Dei; nocne czuwania mnichów.

Keywords: St. Nicetas of Remesiana; De vigiliis servorum Dei; night vigils monks. 
Si sanctus es, ama vigilias, ut thesaurum tuum vigilando custodiens ipse \in sanctitate serveris. Si peccator es, magis curre ut vigilando et orando purgeris [...]". Te słowa zapisane na kartach De vigiliis servorum Dei, autorstwa św. Nicetasa z Remezjany ${ }^{1}$, żyjącego na przełomie IV i V wieku zdumiewają swą mądrością i aktualnością. W swym kazaniu skierowanym do mnichów autor naucza, że czuwania powinny być praktykowane przez każdego mnicha bez wyjątku (Si sanctus es...si peccator es). Dążenie do doskonałości ewangelicznej wymaga stałego czuwania, częstych umartwień, choć podejmowanych z umiarem i roztropnością.

Nadrzędnym celem niniejszego artykułu jest zaprezentowanie stanowiska św. Nicetasa z Remezjany na temat czuwań nocnych. Temat zostanie przedstawiony w następujących odsłonach. Po pierwsze, podamy definicję słowa „czuwanie” przedłożoną przez Biskupa Remezjany oraz przywołamy jego stanowisko odnośnie czasu podejmowania czuwań, a także powiemy pokrótce o 4 kategoriach chrześcijan, którzy odnoszą się z niechęcią do czuwań nocnych. Po drugie, przedłożymy refleksje Nicetasa na temat starodawności czuwań i ich autorytetu. Po trzecie, odpowiemy na pytanie, dlaczego warto podejmować nocne czuwania, czyli zreferujemy opinię Nicetasa na temat użyteczności czuwań. Na koniec przywołamy praktyczne rady, jakich Nicetas udziela czuwającym mnichom. Teksty wyjęte $\mathrm{z}$ De vigiliis servorum Dei podajemy w tłumaczeniu własnym².

\section{Definicja słowa „Czuwanie”}

Pod słowem „czuwanie” (łac. vigilia od czas. vigilare) Nicetas rozumie trud podejmowany przy świetle lampy, czyli porą nocną przez ludzi odznaczających się pilnością czy też gorliwością, o czym wspomina na początku De vigiliis:

1 Zob. wybrana bibliografia dotycząca św. Nicetasa z Remezjany oraz jego dzieł: B. Degórski, Katechezy przedchrzcielne Nicetasa z Remezjany, s. 107-111; K. Gamber, Das „Te Deum” und sein Autor, s. 318-321; K. Gamber, Fragen zu Person und Werk des Bischofs Niceta von Remesiana, s. 222-231; G. Guttilla, La preghiera di Niceta per Paolino di Nola del Carm. 27 e la sua componente geronimiana, s. 109-127; M. Martin, Note retoriche ed esegetiche su Niceta di Remesiana: il „De psalmodiae bono”, s. 309-335; G. Morin, Nicéta de Rémésiana: sa vie et ses oeuvres, s. 97-101; W. A. Patin, Niceta, Bischof von Remesiana als Schriftsteller und Theologe; P. Ressa, Niceta di Remesiana e l'eresia, s. 153-172; C. Riggi, La figura di Niceta di Remesiana secondo la biografia Gennadiana, s. 189-200; A. Soroceanu, Niceta von Remesiana: Seelsorge und Kirchenpolitik im spätantiken unteren Donauraum; C. Springer, Nicetas and the authorship of the „Te Deum”, s. 325-331.

2 Zob. Św. Nicetas z Remezjany, O czuwaniach sług Boga, wstęp i tłum. M. Jóźwiak. 
Dignum est, fratres, aptumque prorsus satisque conveniens de sanctis vigiliis nunc dicere et proferre sermonem, quando ipsa lucubratio geritur a sollicitis ${ }^{3}$.

Pod koniec pierwszego rozdziału Nicetas krytykując tych, którzy nie dostrzegają sensu oraz głębi czuwań nocnych, doprecyzowuje, że czuwania, będące bardzo pożytecznymi dzięki duchowemu trudowi, powinny się składać z modlitw, śpiewania psalmów oraz czytania i rozważania fragmentów Pisma Świętego:

mirari me fateor esse aliquos qui sacras vigilias tam spiritali opere fructuosas, orationibus hymnis lectionibus fecundas, aut superfluas aestimant aut otiosas aut (quod his est deterius) inportunas 4 .

\section{Czas podejmowania czuwań}

Nicetas, zalecając mnichom praktykowanie czuwań nocnych, dookreśla w rozdziale III De vigiliis, że dobrą rzeczą jest wydzielić na czuwanie raz na tydzień pewną część dwóch nocy, a mianowicie soboty i niedzieli, które w jego opinii są jak gdyby oczyszczeniem pozostałych pięciu dni tygodnia, w czasie których mnisi kalają się ziemskimi sprawami:

Nec sane onerosum vel difficile videri debet etiam delicatis corporibus in septimana duarum noctium, id est sabbati atque dominici, portionem aliquam Dei ministerio deputare: ista enim quasi purificatio est dierum quinque vel noctium, quibus stupore carnali ingravescimus aut mundanis actibus obsoletamur ${ }^{5}$.

3 Nicetas, De vigiliis servorum Dei, ed. C. H. Turner, s. 306. Tłum.: „Godną i całkiem stosowną [rzeczą] jest i zupełnie właściwą, bracia, mówić teraz o świętych czuwaniach i przedłożyć mowę, kiedy ta właśnie praca przy świetle lampy jest wykonywana przez [ludzi] bardzo gorliwych" (M. Jóźwiak, O czuwaniach, s. 13).

4 Ibidem, s. 306. Tłum.: „dziwię się, iż są tacy, którzy sądzą, że święte czuwania tak bardzo pożyteczne dzięki duchowemu trudowi, obfitujące w modlitwy, hymny, czytania, są albo zbyteczne, albo niepotrzebne, albo (co dla nich jest gorsze) uciążliwe” (M. Jóźwiak, O czuwaniach, s. 15).

5 Ibidem, s. 307. Tłum.: „I bynajmniej nie powinno wydawać się uciążliwym czy też trudnym także dla ciał kruchych, przeznaczenie na służbę Boga [raz] na tydzień pewnej części dwóch nocy, to znaczy soboty i niedzieli: otóż te są jakby oczyszczeniem pięciu dni czy też nocy, [w czasie] których zmagamy się z ziemskim odrętwieniem albo plamimy się świeckimi sprawami” (M. Jóźwiak, O czuwaniach, s. 21). 


\section{Stosunek chrześcijan do czuwań}

Całe dzieło Biskupa Remezjany jest laudacją czuwań nocnych, które w jego przekonaniu są środkiem do osiągnięcia doskonałości chrześcijańskiej. Tym samym autor De vigiliis strofuje tych, którzy nie podzielają jego zdania na temat czuwań. Nicetas wylicza 4 kategorie chrześcijan, dla których nocne czuwania są zbyteczne, uciążliwe albo budzą w nich odrazę. A mianowicie zalicza do nich ludzi gnuśnych, ospałych, starców oraz ludzi schorowanych:

Quomodo enim profanis religiosa placere possunt, quibus si placerent, nostri essent quod sumus, utique christiani? Si vero nostri sunt quos vigiliarum salutifer actus offendit (ut nihil de his deterius suspicer), aut pigri sunt aut somniculosi aut senes sunt vel infirmi ${ }^{6}$.

Następnie, powołując się na autorytet Pisma Świętego, nawołuje do opamiętania:

Si pigri sunt erubescant, quia illis insonant verba Salomonis "Vade ad formicam, o piger, et aemulare vias eius". Si somniculosi sunt, expergiscantur, scriptura proclamante: „O piger, quousque dormis? Quando autem de somno surgis?” [...]. Si senex es, quis te compellit ut vigiles? Quamquam et non compulsus pro aetate tamen vigilare debes [...]. Si vero infirmus es membris, quod facere non potes noli reprehendere: immo riga et tu secundum prophetam lacrimis stratum tuum et dic „Si memor fui tui super stratum meum"7.

6 Ibidem, s. 306. Tłum.: „Jak bowiem bezbożnikom [sprawy] religijne mogą się podobać, gdyby im się podobały, byliby nasi, gdyż jesteśmy bez wątpienia chrześcijanami? Jeśli zaś naszymi są, a zbawienne dzieło czuwań budzi w nich niechęć (tak że o nic gorszego ich nie podejrzewam), albo gnuśni są, albo ospali, albo są starcami, a może [są] chorzy" (M. Jóźwiak, O czuwaniach, s. 17).

7 Ibidem, s. 306-307. Tłum.: „Jeśli gnuśni są, niech się wstydzą, ponieważ słowa Salomona grzmią dla nich: „Do mrówki się udaj, leniwcze i naśladuj jej drogi” (Prz 6, 6). Jeśli ospali są, niech się ockną, ponieważ Pismo Święte nawołuje: „Leniwcze, jak długo będziesz spał? Kiedy zaś ze snu powstaniesz?” (Prz 6, 9). [...]. Jeśli starcem jesteś, kto cię zmusza, abyś czuwał? Chociaż i nie zmuszany z racji wieku jednak powinieneś czuwać [...]. Jeśli zaś jesteś chory na ciele, tak że nie możesz [tego] czynić, nie chciej krytykować, co więcej i ty zgodnie [ze słowami] proroka zwilżaj łzami łoże twoje i mów: „Jeśli wspominałem ciebie na moim posłaniu” (Ps 62, 7)” (M. Jóźwiak, O czuwaniach, s. 17 i 19). 


\section{Starodawność i autorytet czuwań}

W literaturze patrystycznej punktem odniesienia refleksji była Biblia. Ojcowie Kościoła i pisarze chrześcijańscy swoje refleksje opierali na Piśmie Świętym i niejako nim „myśleli”. Zatem nie dziwi, że omawiane dziełko obfituje w cytaty i skojarzenia biblijne, gdyż autor zawsze tam, gdzie istnieje taka możliwość, czyni nawiązania do rozmaitych fragmentów z Pisma Świętego. Nicetas, mówiąc o starodawności i autorytecie czuwań, powołuje się na świadectwa ze Starego oraz Nowego Testamentu.

Na początku przedkłada mnichom przed oczy postawę proroka Izajasza oraz króla Dawida, podejmujących i wysławiających czuwania:

Antiqua est vigiliarum devotio, familiare bonum omnibus sanctis. Esaias denique propheta clamat ad Dominum „De nocte vigilat spiritus meus ad te, Deus, quoniam lux praecepta tua super terram". David, et regio et prophetico sanctificatus ungento, ita canit „Domine Deus salutis meae, in die clamavi et nocte coram te”.

Kilka wersetów niżej, powołując się na inny Psalm Dawidowy pyta z nutką ironii, czy Dawid śpiewał psalmy, rozłożony na swym łożu. I następnie dodaje, że dobrą rzeczą jest pamiętać o Bogu w każdym miejscu, lecz lepszą jest wstawić się przed obliczem boskim w postawie gotowości, mając na uwadze zalecenia Dawida, ukazującego czas, miejsce i postawę zanoszącego modlitwy, co stanowi kolejny argument na korzyść czuwań, podejmowanych w nocy:

Sed forsitan in lectulo suo positus haec cantabat: quod aliquanti pigriores sufficere putant, si tantum in stratu suo aut oret unusquisque aut psalmum forte submurmuret. Quod quidem et ipsum bonum est; Dei enim semper et ubique meminisse salutare est. Sed quod sit melius exsurgentem conspectui divino assistere, accipe eiusdem prophetae aliam vocem quae et tempus et locum et habitum deprecantis ostendit: „In noctibus inquit extollite manus vestras in sancta et benedicite Dominum".

8 Ibidem, s. 308. Tłum.: „Gorliwość o czuwania jest od dawna, a korzyść [ich jest] znana dla wszystkich [ludzi] świętych. Już prorok Izajasz woła do Pana: „Podczas nocy duch mój czuwa przy tobie, Boże, ponieważ światło twoje sprawuje rządy nad ziemią” (Iz 26, 9 wg LXX). Dawid, uświęcony przez namaszczenie królewskie i kapłańskie, śpiewa w ten sposób: „Panie Boże zbawienia mojego, za dnia wołałem i w nocy [byłem] przed tobą" (Ps 87, 2)” (M. Jóźwiak, O czuwaniach, s. 23).

9 Ibidem, s. 308. Tłum.: „Lecz, czy może [Dawid] rozłożony na swym łożu te śpiewał, co niektórzy bardziej leniwi sądzą, że wystarczającym [jest], jeśli tylko każdy albo na posłaniu swoim będzie się modlił, albo może psalm będzie nucił. Co z pewnością i samym 
Biskup Remezjany przechodząc do świadectw z Nowego Testamentu wskazuje między innymi na postawę pasterzy, którzy z racji czuwań nocnych nad swą trzodą, dostąpili łaski ujrzenia narodzonego Chrystusa. A zatem w przekonaniu autora De vigiliis czuwania nocne zsyłają łaski na czuwającego:

Pastores illi sanctissimi, dum super gregem suum nocturnas exercent vigilias, et angelos in splendore videre et Christum natum in terris primi audire meruerunt ${ }^{10}$.

W innym passusie zaświadczając o autorytecie czuwań, Nicetas powołuje się na samego Jezusa, który praktykował czuwania nocne, aby dać swoim sługom przykład, cóż powinni czynić:

Pernoctabat Dominus [non sibi, sed] ut scirent servi inopes et infirmi quid agere deberent, quando Dominus, dives in omnibus nec ullius indigens quasi fortissimus, pernox in oratione duraret ${ }^{11}$.

Następnie w rozdziale 7 De vigiliis przedkłada mnichom rozmaite przykłady na to, że sami Apostołowie czuwali i zalecali czuwania. A zatem starodawność i autorytet czuwań, są głęboko zakorzenione w Biblii i mają solidny fundament, stąd ich wartość jest niepodważalna i bezdyskusyjna.

\section{Użyteczność czuwań}

Nicetas, pisząc o użyteczności czuwań, podkreśla na wstępie, że każdy człowiek, skory jest podjąć dany trud, jeśli przedłoży mu się użyteczność tego trudu. Mając tę świadomość wylicza skrupulatnie w De vigiliis realne korzyści, jakie płyną z podejmowania czuwań nocnych. Dodaje jednak, że sama użyteczność

dobrem jest; Zbawienną [rzeczą] jest pamiętać o Bogu zawsze i wszędzie. Lecz lepszym jest to, aby powstał i wstawił się przed obliczem boskim, przyjmij pewne zalecenie tego samego proroka, które ukazuje i czas i miejsce i postawę zanoszącego błagania: „W [czasie] nocy, mówi, wznieście wasze ręce ku świątyni i błogosławcie Pana” (Ps 133, 2)” (M. Jóźwiak, O czuwaniach, s. 23 i 25).

10 Ibidem, s. 309. Tłum.: „Owi najświętsi pasterze, podczas gdy ćwiczyli się w czuwaniach nocnych nad swoją trzodą, stali się godnymi ujrzeć aniołów w blasku i usłyszeć jako pierwsi na ziemi o narodzeniu Chrystusa” (M. Jóźwiak, O czuwaniach, s. 31).

11 Ibidem, s. 310. Tłum.: „Pan spędził całą noc [na modlitwie] nie dla siebie, lecz aby słudzy bezużyteczni i słabi poznali, cóż czynić powinni, kiedy Pan bogaty we wszystko i nie odczuwający braku niczego, jak gdyby najmożniejszy, trwał przez całą noc na modlitwie" (M. Jóźwiak, O czuwaniach, s. 33). 
stanie się bardziej zrozumiała dla danej osoby poprzez podjęcie konkretnego trudu, aniżeli poprzez słowo mówione czy też pisane. Tym samym zachęca do działania. Wśród korzyści, jakie płyną z praktykowania czuwań nocnych, biskup Remezjany, wylicza ${ }^{12}$ :

- pozbycie się uśpienia umysłu,

- oświecenie duszy czuwającego,

- otrzymanie łaski,

- oddalenie się bojaźni,

- zrodzenie się ufności,

- umocnienie w postawie czystości,

- ustąpienie głupoty, a nabycie roztropności,

- udoskonalenie się umysłu,

- zranienie diabła mieczem Ducha Św.

Po wyliczeniu tych korzyści, Nicetas pyta z nutką ironii w głosie:

Quid hac utilitate maius? Quid istis lucris commodius? Quid hac delectatione suavius? Quid ista felicitate beatius, teste etiam propheta qui in principio psalmorum suorum beatum virum describens, summam beatitudinis eius in hoc versiculo collocavit „Si in lege Domini meditetur die ac nocte” ${ }^{\text {. }}$.

Poniżej dodaje, że słuszną rzeczą jest modlitwa i rozmyślanie, podejmowane za dnia, lecz milsze Bogu i skuteczniejsze jest nocne rozmyślanie, gdyż za dnia rozmaite prace i zajęcia, absorbując umysł, stoją na przeszkodzie. A zatem tutaj Nicetas uwypukla praktyczny aspekt podejmowania czuwań w nocy:

12 Ibidem, s. 311: „Gustando enim videtur quia suavis est Dominus» (Ps 33, 9), sicut scriptum est. Qui ergo gustavit, intellegit et sentit quantum pondus pectoris vigilando deponitur, quantus mentis stupor excutitur, quanta lux animam vigilantis et orantis inlustrat, quae gratia quae visitatio membra universa laetificat. Vigilando timor omnis excluditur, fiducia nascitur; caro maceratur, vitia tabescunt, castitas roboratur; cedit stultitia, accedit prudentia; mens acuitur, error obtunditur; criminum caput diabolus gladio Spiritus vulneratur".

13 Ibidem, s. 311. Tłum.: „Cóż [jest] cenniejszego od tej użyteczności? Cóż korzystniejszego od takiego zysku? Cóż milszego od takiej radości? Cóż bardziej uszczęśliwiającego od tego szczęścia, kiedy [istnieje] świadectwo proroka, który opisując na początku swoich psalmów człowieka szczęśliwego, umieścił pełnię jego szczęśliwości w tym wersecie: „Jeśli w Prawie Pana będzie rozmyślał dniem i nocą" (Ps 1, 2)” (M. Jóźwiak, O czuwaniach, s. 39 i 41). 
Bona est quidem diurna meditatio, bona oratio, sed multo gratior et efficacior est nocturna meditatio: quia per diem necessitates variae obstrepunt, occupationes distrahunt mentem, sensum multiplex cura dispergit; nox autem secreta, nox quieta, oportunam se praebet orationibus, aptissimam vigilantibus, dum carnalibus occupationibus expeditum collecto sensu totum hominem divinis conspectibus sistit ${ }^{14}$.

\section{Praktyczne zalecenia dla czuwających mnichów}

Pierwszym z zaleceń, jakie Nicetas kieruje do czuwających mnichów, jest to, aby czuwanie podjęte przez ciało, było także czuwaniem serca, ducha i umysłu:

Tantum, karissimi, qui vigilat oculis vigilet et corde, qui orat spiritu oret et mente; quia nec satis utile est oculis vigilare et animo dormitare $[\ldots]^{15}$.

Druga praktyczna rada dotyczy spożywania pokarmów i napojów przez czuwających mnichów. Biskup Remezjany przestrzega przed obżarstwem oraz opilstwem, które przeszkadzają w podejmowaniu czuwań:

Curandum est etiam ne nimietate cibi vel potus vigilantis pectus oneretur, nec foeditate ructantes et crapula non solum ipsi nobis insuaves simus sed etiam gratiae Spiritus indigni iudicemur ${ }^{16}$.

Poniżej wyjaśnia, że mnich, chcąc podjąć święte czuwania, powinien uwolnić się od wszelkich rzeczy, które go obciążają:

14 Ibidem, s. 311. Tłum.: „Z pewnością dobrą [rzeczą] jest rozmyślanie za dnia, dobra [taka] modlitwa, lecz o wiele bardziej milsze i skuteczniejsze jest nocne rozmyślanie, ponieważ za dnia różne okoliczności stoją na przeszkodzie, zajęcia absorbują umysł, rozmaita troska zaprząta myśl; noc zaś [jest] tajemnicza, noc [jest] cicha, okazuje się dogodną [porą] dla modlących się, najodpowiedniejszą dla czuwających, podczas gdy całego człowieka, który otrzymał oświecenie, uwolnionego od ziemskich zajęć, pozostawia przed boskim majestatem" (M. Jóźwiak, O czuwaniach, s. 41).

15 Ibidem, s. 312. Tłum.: „Tylko, najdrożsi, kto czuwa oczami, niech i czuwa sercem, kto modli się duchem, niech i modli się umysłem; gdyż mało użytecznym jest czuwać oczami, a spać w duchu [...]" (M. Jóźwiak, O czuwaniach, s. 43).

16 Ibidem, s. 312. Tłum.: „Także trzeba dbać o to, aby żołądek czuwającego nie był obciążony zbyt wielką ilością jedzenia czy też picia i aby nie wymiotowali z obrzydzeniem, a z powodu obżarstwa nie tylko sami dla siebie stajemy się odrażający, lecz także jesteśmy uznawani za niegodnych łaski Ducha Świętego" (M. Jóźwiak, O czuwaniach, s. 43). 
Ergo, tamquam divino fungendo ministerio, ante nos per abstinentiam parare debemus, ut ingravantibus expedit libere vigilare possimus ${ }^{17}$.

Innym zaleceniem autora De vigiliis jest odparcie przez czuwających wszelkich złych myśli, by nie sprowadzili oni na siebie grzechu. A także trzeba być roztropnym i mieć na uwadze, że istnieją także czuwania, pochodzące od diabła:

Cogitatio quoque mala pellatur, ne male vigilantis „Oratio fiat” sicut legitur „in peccatum”. Sunt enim et ex maligno vigiliae, sicut in Proverbiis legitur quia „ablatus est somnus ab oculis eorum: non enim dormiunt inquit nisi male fecerint" ${ }^{\prime \prime}$.

Ciekawa jest rada skierowana do mnichów w podeszłym wieku, którzy z racji słabości ciała nie mogą podejmować już czuwań w postawie stojącej. Biskup Remezjany, kierowany troską duszpasterską o formację nowicjuszy, poucza, że młodych mnichów nie powinno się posyłać do tych schorowanych, gdyż mogą oni stać się przyczynkiem do zaniechania praktyki czuwań. Kiedy zaś nowicjusze stają wobec rozmaitych pokus młodości, powinni pielęgnować podejmowanie czuwań nocnych:

Et si stare non potes, et tuam cogitas inpossibilitatem, non debes iuvenes et valentes ad tuum revocare torporem, quod propter varias temptationes iuventutis se ipsos propensioribus macerare debent vigiliis ${ }^{19}$.

17 Ibidem, s. 312. Tłum.: „Przeto, sprawując jak gdyby boską służbę, powinniśmy najpierw przygotować siebie poprzez umiarkowanie, abyśmy swobodnie mogli czuwać, wolni od [jakichkolwiek] obciążeń" (M. Jóźwiak, O czuwaniach, s. 43).

18 Ibidem, s. 312. Tłum.: „Także trzeba odeprzeć [każdą] złą myśl, aby „nie stała się grzechem modlitwa” (Ps 108, 7) źle czuwającego, tak jak czytamy [w Psalmie]. Istnieją bowiem i czuwania, [które pochodzą] od złego, jak podaje Księga Przysłów: „ponieważ sen został odsunięty od ich oczu: nie śpią bowiem, mówi, jeśli nie uczynią [czegoś] złego" (Prz 4, 16)" (M. Jóźwiak, O czuwaniach, s. 43 i 45).

19 Ibidem, s. 307. Tłum.: „A jeśli nie możesz stać i rozmyślasz o twojej niemożności, nie powinieneś przywoływać do twego paraliżu młodzieńców i zdrowych na ciele, gdyż z powodu rozmaitych pokus młodości powinni zmiękczać siebie samych za sprawą czuwań bardzo [im] pomocnych" (M. Jóźwiak, O czuwaniach, s. 17 i 19). 


\section{Konkluzja}

Nocne czuwania sięgają korzeniami początków Kościoła, gdyż chrześcijanie chcąc naśladować modlącego się w nocy Chrystusa i wypełnić Jego wezwanie do czuwania, zbierali się na nocnej modlitwie.

De vigiliis servorum Dei autorstwa Nicetasa z Remezjany jest laudacją na cześć czuwań nocnych, które powinny stać się udziałem każdego mnicha, dążącego do wypełnienia rad ewangelicznych. W opinii biskupa Remezjany praktykowanie czuwań nocnych jest jedną z metod na osiągnięcie doskonałości zakonnej. Nicetas, zachęcając mnichów do podjęcia czuwań, opiera swoje refleksje na autorytecie Pisma Świętego. W swoim kazaniu poucza mnichów o starodawności i autorytecie czuwań nocnych, a co ważniejsze wylicza konkretne korzyści, jakie stają się udziałem czuwającego. Ten praktyczny aspekt sprawia, że zalecenia kierowane do mnichów, nie są zbiorem suchych rad, lecz wskazują na prawdziwą troskę duszpasterską biskupa o lud mu powierzony.

\section{Bibliografia}

\section{Źródła}

Nicetas, De vigiliis servorum Dei, ed. C. H. Turner, Journal of Theological Studies 22 (1921), s. 305-320.

Św. Nicetas z Remezjany, O czuwaniach stug Boga, wstęp i tłum. M. Jóźwiak, Biblioteka Patrystyczna, Wrocław 2015.

\section{Opracowania}

Degórski, B., Katechezy przedchrzcielne Nicetasa z Remezjany, Vox Patrum 18 (1990), s. $107-111$.

Gamber, K., Das „Te Deum” und sein Autor, Revue Bénédictine 74 (1964), s. 318-321.

Gamber, K., Fragen zu Person und Werk des Bischofs Niceta von Remesiana, Römische Quartalschrift für christliche Altertumskunde und für Kirchengeschichte 62 (1967), s. 222-231.

Guttilla, G., La preghiera di Niceta per Paolino di Nola del Carm. 27 e la sua componente geronimiana, Augustinianum 46, 1 (2006), s. 109-127.

Martin, M., Note retoriche ed esegetiche su Niceta di Remesiana: il „De psalmodiae bono", Vetera christianorum 33, 2 (1996), s. 309-335.

Morin, G., Nicéta de Rémésiana: sa vie et ses oeuvres, Revue Bénédictine 23 (1906), s. $97-101$. 
Patin, W.A., Niceta, Bischof von Remesiana als Schriftsteller und Theologe, München 1909;

Ressa, P., Niceta di Remesiana e l'eresia, Classica et Christiana 1 (2006), s. 153-172.

Riggi, C., La figura di Niceta di Remesiana secondo la biografia Gennadiana, Augustinianum 24 (1984), s. 189-200.

Soroceanu, A., Niceta von Remesiana: Seelsorge und Kirchenpolitik im spätantiken unteren Donauraum, Frankfurt 2013.

Springer, C., Nicetas and the authorship of the „Te Deum”, Studia Patristica 30 (1997), s. 325-331. 